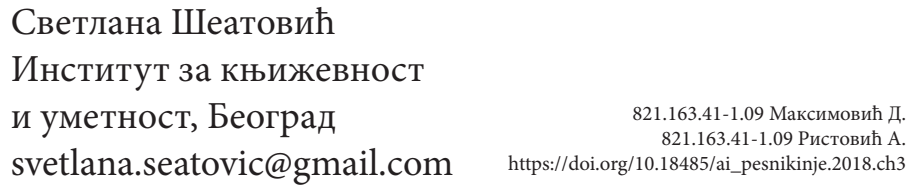

\title{
ПОЕЗИЈА ДЕСАНКЕ МАКСИМОВИЋ И АНЕ РИСТОВИЋ - ОБЛИЦИ АУТОХТОНОГ ПЕСНИЧКОГ РАЗВОЈА ${ }^{1}$
}

У раду се анализирају аутентични облици песничког развоја Десанке Максимовић и Ане Ристовић. Оба пута су обележена самосвојним токовима, а рад указује на особености њиховог песништва и истрајност у личном развојном путу. Обе песникиње припадају различитим генерацијама, па баш због тога рад анализира нихову блискост главним токовима и специфичност поетичких поступака.

Кључне речи: Десанка Максимовић, Ана Ристовић, женско песништво, интимни тон, поетика, естетска валоризација, комуникативност.

\section{Ойщӣи ӣоїлеg}

Андрићград је право место где треба говорити и о женама песникињама јер ко је у нашој књижевности дубље и истрајније проучавао и описао природу жене на нашим просторима од Иве Андрића. Позиција српских песникиња је често сродна месту и положају жене на Балкану. Поред естетских разлога српске пес-

1 Рад је настао у оквиру пројекта Смена йоейичких йараgиімми у срйској књижевностии 20. века-национални и евройски коне$\overline{\mathcal{u}} \kappa с \overline{\mathcal{u}}(178016)$ у Институт за књижевност и уметност, Београд. 
никиње су биле и део друштвеног миљеа који је увек прожимао књижевност без обзира на историјске, државотворне или политичке околности. Уколико су те околности биле лошије толико је било мање песникиња или су њихови домети били скромнији и у естетском и друштвеном животу. Без обзира на становишта модерних и чак популарних књижевнотеоријских тенедеција чињеница наше културе говори о малом броју песникиња и још мањој критичкој валоризацији кроз антологије, награде, па на крају и утицајност у друштву. Од Јефимије и њеног ренесансног стиха „Утишај буру страсти душе и тела мојега“ у молитвеном тону у „Похвали кнезу Лазару“ који одзвањају као вапај младе жене и удовице, монахиње која на развалинама српске државе са кнегињом Милицом обавља дипломатске, културне и државотворне функције до данас ми можемо пратитити само усамљене гласове жена песникиња у српској књижевности. Да ли се било шта променило од Јефимијиног скрушеног, али болног молитвеног гласа? Векови су прошли у тами српске културе, а посебно књижевности. Тек после готово 400 година имамо Милицу Стојадиновић Српкињу у размаху романтичарских заноса и то није случајност и из историјских и културолошких разлога. Ипак, 20. век је пружио више могућности за образовање жена, књижевне часописе, јавну културну сцену која посебно у другој половини минулог века постаје све доступнија. У књижевној историји као и у актуелном књижевном животу значајно место су имале Даница Марковић, једина жена песникиња у модернизму, а потом Аница Савић Ребац, Јелена Димитријевић, Јела Спиридоновић Савић и Десанка Максимовић. Ипак, жене песникиње су и у том отворенијем друштву биле мало присутне. Ми можемо говорити о њиховом постојању кроз часопи- 
се Жена и свети и то посебно оне који су усмерени на позицију жене, али у антологијама налазимо процентуално изузетно мали број песникиња. Зашто књижевна критика остаје релативно тиха према песништву жена песникиња? Да ли су у основи свега естетски разлози? Десанка Максимовић је једина песникиња која је опус започела 1920. у веома блиским контактима са савременицима, Црњанским, Винавером, Дединцем, Растком Петровићем, после Другог светског рата са Васком Попом, Миодрагом Павловићем, Оскаром Давичом и једина је својим дугим биолошким и песничким ангажманом опстала у свету који је на неки чудан начин био резервисан за мушкарце. Последње деценије 20. века обележила је поезија Радмиле Лазић, Тање Крагујевић, Мирјане Стефановић, а у новијем периоду Ане Ристовић и Милене Марковић. То су малобројна имена песникиња високог естетског домета, неке од њих су и револуционарног поетичког усмерења, али су најчешће обележене путевима аутентичног развоја. Антологија Мачке не иgу у рај (2000) коју је приредила Радмила Лазић је прва естетска и антологијска валорозација жена песникиња. Радмила Лазић прва врши ревалоризацију поезије жена и у том смислу је једина антологија која је сабрала најзначајнија имена српског песништва. У савременом тренутку је антологија Проїнани Орфеји (2015) Ненада Грујића мало померила место женског песништва.

Десанка Максимовић - трајност и успон

Десанка Максимовић је једина песникиња која је успела да од 1920. године када објављује прве песме до 1993. године остане своја, аутентична у поетичком смислу и да само повремено буде део главних токова 
којима су припадали остали песници. Популарност је била непревазиђена до сада у српској књижевности. Песникиња са 78 књига од чега је преко 50 збирки песама и још бар 20 избора је феномен наше културе и књижевности. Тајна биолошког и песничког трајања је тајна Десанке Максимовић. Ове године 16. маја обележено је 120 година од рођења ове песникиње у родној Бранковини. У нашим сећањима остала је као старица са шеширом за коју ће владика шабачки Лаврентије казати да је била „Старица у којој је било више духа него тела“. Живела је 95 година, радила до последњег тренутка бритког ума и веселог духа. Са годинама је све више мењала песме тако да се у рукописној заоставштини налази огроман број варијанти појединих песама. Обожавана песникиња која је била симбол трајања, мере света и века у коме је опстајала упркос свим менама. Остала је своја, аутентична, увек блиска бројним савременицима од Милоша Црњанског са којим је студирала, читала радну верзију Дневника о Чарнојвићу раних двадесетих, Симе Пандуровића који је био њен професор немачког језика и уредник часописа Мисао у коме је штампала прве песме 1920. године до модерних песника послератног доба са којима је сарађивала: Васком Попом, Душаном Матићем, Миодрагом Павловићем и другима. Увек блиска и отворена за нове токове, али никад део покрета, смера, групе. Никоме није била ближа у раним збиркама Песме (1924), Зелени ви$\bar{u} е з$ (1930) него Јовану Дучићу. У Срйском књижевном іласнику и Пен клубу двадесетих година Десанка Максимовић је упознала Јована Дучића и Милана Ракића. У фебруару 1935. године Дучић ће казати: „Код нас је Десанка, по мом мишљењу, лиричар првог ранга." (Поповић 1960: 12) коме највише дугује у стилу, тону, мелодиозности, распону расположења, модернистичким 
одликама поезије пре Првог светског рата. Међутим, поезија Десанке Максимовић је писана слободним стихом, новим духом и сензибилитетом песника 20их година 20. века, али без оповргавања традиције као што ће то радити авангардисти (Милош Црњански, Растко Петровић). У раној фази то је поезија симболистичких синестезија, нијанси, импресија, колоритност природних тонова зеленог и плавог. Наслови тих песама све казују „Стрепња“, „Чежња“, „Предосећање“, „Једна смрт“, „Слутња“, „Тајна“, „Поноћ“, али ту су и „Пролеће“, „Сутон“, „Рађање месеца“, „Сунчев залазак“. Мотивски и тематски дијапазон Дучићеве поезије са којом се у потпуности сусреће у сфери љубави, смрти, Бога, али се помера ка изворима народних веровања и паганских култова. Данас готово да нема особе која није запамтила суптилност првих љубавних доживљаја у импресионистичким наговештајима и сугестијама у стиховима: „Не, немој ми прићи!“ у песми „Стрепња“. У таквој способности да ухвати детаљ природе и човека Десанка Максимовић се формирала на наслеђу нашег модернизма. С друге стране, она је блиска космичким идејама Сибе Миличића утапајући се у природу, снагу универзума непрестано се радујући животу. Радост трајања и живљења упркос свему је још једна велика тајна Десанке Максимовић. Поезија Десанке Максимовић у првим збиркама је везана за теме љубави, смрти и Бога. Како је приметила Љубица Ђорђевић ${ }^{2}$ било је то у време када Дучић објављује своје циклусе о богу, смрти и љубави од 1923. до 1925.

После Другог светског рата мењала се поетичка парадигма Десанке Максимовић померајући клатно са традиционалног на модеран израз који ће највиши степен достићи у збирци Тражим йомиловаюе и Немам

2 Видети: Љубица Ђорђевић, Песничко gело Десанке Максимовић, ИП Пешић и синови, 1998, стр. 50. 
више времена (1973), Лейойис Перунових ӣойомака (1976) док ће варијације са јапанском поезијом и хаику изразом бити доминантне у Озону завичаја. Веома близак развојни ток налазимо и код Ане Ристовић, песникиње која је прву збирку објавила само годину дана после смрти Десанке Максимовић. Било би сасвим неприкладно писати о поетичким сродностима ове две песникиње, али можемо указати на парадигматичан облик развоја, аутохтону путању која се неће додворавати критици или водећим групама, струјама, тендецијама. Популарност и висок есетски ниво поезије Ане Ристовић представља паралелу путу и развоју песништва Десанке Максимовић. Комуникативност њихове поезије је њихов заједнички именитељ од кога би могли да пођемо у оваквом тексту. Десанка Максимовић је у досадашњим бројним студијама Љубице Ђорђевић, Станише Тутњевића ${ }^{3}$, Слободана Ж. Марковића, Ане Ћосић Вукић, Александре Вранеш ${ }^{4}$, Душана Иванића ${ }^{5}$, Александра Петрова, Ранка Поповића ${ }^{6}$ ту-

3 Видети: Станиша Тутњевић, „Приступ цјелокупном дјелу Десанке Максимовић“, Hag целокуйним gелом Десанке Максимовић, (ур. Станиша Тутњевић), Задужбина „Десанке Максимовић“, Београд, 2013, 9-33; Слободан Ж. Марковић, „Природа-везивно ткиво стваралаштва Десанке Максимовић“, исто, 35-41, Ана Ћосић Вукић, „Десанка Максимовић као књижевни критичар“, исто, 181-201.

4 Александра Вранеш, „Из рукописа Десанке Максимовић“ у:

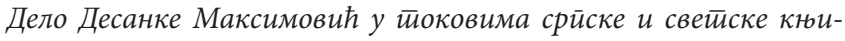
жевносити, (ур. Слободан Ж. Марковић), Задужбина „Десанке Максимовић“, Бероград, 2000, 132-138.

5 Видети: Душан Иванић, „Ка оптималном критичком издању“, Збирка Тражим ӣомиловане (ур. Ана Ћосић Вукић), Задужбина „Десанка Максимовић“, Београд, 2007, 83-92; Александра Петров, „С Богом их је троје“, исто, 5-66.

6 Видети: Ранко Поповић, „Лирски инстикт и вјековито памћење у поезији Десанке Максимовић“, Традицоионално и модерно у ствралаштву Десанке Максимовић, Задужбина „Десанка Максимовић“, Београд, 2008, 55-70. 
мачена старијим методолошким приступима док су у последњих десет година све чешће модерније анализе које су усмерили пажњу на интертекстуалност ${ }^{7}$, слојеве културе и историје, односа паганског и хришћанског, варијантности и других текстолошких питања. Место Десанке Максимовић у послератној српској поезији је комплексно питање као и њена целокупна позиција у развоју српске књижевности. Док је у првим збиркама много ближа модернистима и слободном стиху, а потом социјалној литератури тридесетих година у послератном периоду усмерена је на дечју поезију, родољубиво песништво, а од средине шездесетих година прилази токовима који се враћају на нашу средњовековну традицију, наслеђе паганске и хришћанске културе. 3бог тога се збирком Тражим йомиловање укључује у токове у којима су већ Миодраг Павловић, Иван В. Лалић, Љубомир Симовић као песници који се враћају традицији и националној култури. Међутим, поетички поступци Десанке Максимовић су сасвим другачији од њених тадашњих савременика. Тражим йомиловағе или Лейойс Перунових йойомака стоје као облици реактивирања средњовековне и најстарије културе народних веровања и паганских божанстава Јужних Словена, али су поетички поступци мање радикални и много мање усмерени на обнову жанрова. Иван В. Лалић, Љубомир Симовић и Миодраг Павловић реактивирају жанр молитве, користе лексику средњег века док Десанка Максимовић само делимично користи језичке и идејне основе старе књижевности. Она урања у тради-

7 Видети зборнике Хришћанско и йаїанско у йоезији Десанке Максимовић, (ур. Ана Ћосић Вукић) 2005; Траяиционално и моgерно у стиваралашиевв Десанке Максимовић (ур. А. Ћосић Вукић) 2008, Збирка Тражим йомиловане (ур. Ана Ћосић Вукић) 2007. Сви зборници у издању Задужбине „Десанке Максимовић“. 
цију са чврстим основама у модерном језику и изразу. Можда је она због тога била и популарнија најширим читалачким круговима јер није значајно подражавала жанрове старе књижевности. Комуникативност њене поезије остаје на високом нивоу према савременој публици у односу на наведене песнике. Мисаона поезија из збирке Немам више времена представља јасан ток модернијег елиптичног израза, сублимног исказа који тежи гномичности, али опет чува свој специфичан лирски глас. Упркос свему Десанка Максимовић је остала песникиња чија поетика и основне особености морају да се испитају и даље у бројним односима традиционалног и модерног које обухвата цео 20. век у нашој поезији као једну општу контроверзу. Посебна је заслуга за проучавање ове песникиње делатност Задужбине „Десанке Максимовић“ која постоји 25 година и у том периоду је објавила више od 10 зборника, едицију са 9 научних монографија и Целокуйна gела у 10 томова. Разумели су је на свим језицима света као што је и сама преводила. У ранијим тумачењима често је била порећена и са Бранком Радичевићем и стражиловском линијом по броју песама које су добиле и музичко извођење. Истраживање Владимира Јовановића ${ }^{8}$ је показало да је преко 175 песама изведено уз музичку пратњу, 43 музичка ствараоца су компоновала дела за текстове или делове текстова Десанке Максимовић. Укупно 117 песама је музички обрађено до 2001. годи-

8 Видети студију Владимира Јовановића о компоновању музичких дела на стихове Десанке Максимовић са прецизном анализом у: Владимир Јовановић, „Дела наших музичких стваралаца компонована на стихове Десанке Максимовић до 2001. године“, Наg целокуйним gелом Десанке Максимовић, (ур. Станиша Тутњевић), Задужбина „Десанке Максимовић“, Београд, 2013, 391-410. 
не. Занимљиво је да су највећу пажњу привукле песме из првих збирки Песме (1924), Гозба на тиваgи (1932) и Песник и завичај (1946), а потом Тражим йомиловате (1964), Немам више времена (1973), Ничија земља (1979) и Озон завичаја (1990).

Напокон, да ли нам треба више доказа о лирској суптилности и аутентичном лирском гласу Десанке Максимовић?! Ако је лирика своје прве кораке направила уз лиру и музичке тактове онда је овај мали дискурс у музику показао да је Десанка Максимовић исконски лиричар минулог века који је имао апсолутно свој ток у који су се уливале делимично реке и речице различитих праваца и школа, али после свега песникиња нас враћа ка праискону лирике у песми „Опорука“:

„Оставићу вам једино речи

ископане из дубине слуха

као благо из кладенца, наслеђене од ветрове фруле, исковане где се срп кује, речи отете с кљуна птици која лети над облацима, речи испретане на огњишту које тајну ватре и пепела знају, реч прочитану немуштем из погледа[...]“

Десанка Максимовић је обележена аутентичним песничким развојем и представља пример јединственог опуса у оквиру српске књижевности 20. века. Поезију Десанке Максимовић видимо као специфичан поетички модел који је увек био посебан у односу на савременике; од првих песама објављених почетком двадесетих година до последњих збирки и песама деведесетих година. У развоју српске поезије Десанка Макисмовић је остала 
симбол лирске суптилности, трајања и популарности.

$$
\begin{aligned}
& \text { Ана Ристиовић - инйимизам }
\end{aligned}
$$

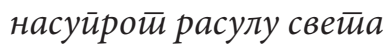

На крају 20. века Ана Ристовић објављује прву збирку песама Сновияна воgа (1994) само годину дана после смрти Десанке Максимовић. Поезија Ане Ристовић је од тада, па све до данас обележена сталним поетичким развојем, изузетном комуникативношћу и изразитим лирским тоном. Ана Ристовић је песникиња која дубоким погледима лирског субјекта, двојношћу и контрапунктним захватима помера границе српског песништва у 21. веку. Док је Десанка Максимовић својим широким опусом посвећеним и деци ушла у бројне читанке, лектире и постала песник народа Ана Ристовић после девете књиге песама постаје једна врста свежег, лирског, самосвојног гласа који тежи највишим естетским дометима. Она припада генерацији деведесетих која се појављује у једној од најтежих деценија за српски народ, културу и књижевност. Ипак, насупрот ратним догађајима била је то деценија највећих песничких књига у најтмурнијем тренутку наших класика (Писмо и Четичри канона Ивана В. Лалића, Сеgмица Милосава Тешића). То је нова генерација коју обележава нови мистицизам, метафизика одсутности, парадоксалност, нова патетичност, аутореторичност како је то приметио Тихомир Брајовић у студији Речи и сенке. Појава интимног као облик бега од социјалних околности представља једну од посебних особина те генерације, а можда понајвише Ане Ристовић. Од гласа интимног и личног емоционалног тона Ана Ристовић је културом и образовањем, високим облицима артифицијелности и интертекстуалности стигла до синтеза знања и искуства, емоције и културе. Обележена мета- 
поетским и аутопоетским исказима поезија Ане Ристовић кореспондира са бројним референцама културе и књижевне баштине градећи сопствени поетички израз обележен искуством писања, мишљења о поезији и метапоетских исказа. То је поезија коју обележава парадокс, иронија, метапоетичност, субјективност, испитивање односа тела и текста, интимности, књижевност на рубу опстанка културе, друштва, света. Тако се и позиција жене поставља као друштвено биће на ивици, на рубу и у процепу независности и природне потребе за природним пореклом жене. У каснијим збиркама Ана Ристовић је и даље на трагу интертекстуалних облика, алузија, асоцијација, али и на путу једноставности исказа, гномичности ослоњене и на искуство песника оца. За прву збирку Сновияна воgа (Књижевна омладина Србије, Београд, 1994) добила је Бранкову награду. Потом следе збирке: Уже оg йеска (1997), Забава за gоконе кћери (1999), Животи на разіледници (2003), Око нуле (2006), П.С. (изабране песме) (2009), Меиееорски

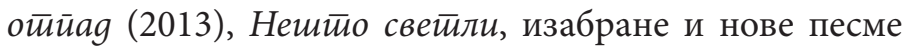
(2014), Чисиична (2015). После Бранкове награде уследила је награда Бранко Миљковић и награда Сајма књига у Игалу за Забаву за gоконе кћери (2000), немачка награда за младу поезију Hubert Burda 2005. године, Милица Стојадиновић Српкиња за збирку P.S. (2010), Дисова награда за песнички опус 2014. године и награда „Десанка Максимовић“ за допринос развоју српске поезије 2018. године. Превођена је на бројне језике, енглески, немачки, словеначки, словачки, мађарски, шведски, шпански, француски, бугарски, фински. Ана Ристовић је и преводилац и до сада је превела више од 20 књига савремене словеначке прозе и поезије. Дакле, свеукупна стваралачка личност у савременој поезији ca 9 песничких књига, два избора са новим песмама 
у којима је стално померала и усавршавала песнички језик, жанр и тематику. Приликом доделе Дисове награде 2014. године у образложењу се каже да је „[...] песникиња чији глас помера границе савременог песништва. Снагом песничких слика и свог савременог израза Ана Ристовић је показала да је савремено српско песништво у једном важном, веома плодном поетичком раздобљу“ (Радуловић 2014: 4). Већ првом збирком она је најављена као песникиња великих поетичких могућности, рафинираног стила, структуре која призива жанр бајке богата лирским и фантастичним елементима потискујући реалност. У првој песми збирке Сновиgне воgе „Проповедање чаролије“ Ана Ристовић отвара пут фантастичном и интимном свету у игри огледала и двојности, сна и сновиђења. У последњим стиховима ове песме као да одређује поетичко језгро збирке: „Веровати у сушти свет унутар огледала/када ни огледала, можда више не постоје“. Ана Ристовић ће једном приликом казати да поезија не може спасити свет, али на одређен начин, спасава оног ко је чита, управо зато што му не нуди никакве одговоре већ буди у њему самом запитаност о свету (Ристовић 2014а: 6). Та врста запитаности над светом и књижевност као нека врста терапије читалаца и ставаралаца је блиска стиху Десанке Максимовић: „Земља јесмо, све остало су привиди/ Једино није привид рана која се у ноћ отвара и бриди“. Поезија као облик мисаоности, превазилажења стварности и свест о емоционалном супстрату као једином уточишту. У том погледу Ана Ристовић даје допринос развоју српске поезије ширећи његов поетички и стилски домет новим жанровским померањима као у збирци Животи на разілесници (2003).

Прва збирка Сновияна воgа се структуром усмерава на огледала, мимикрију леда, игре лика и његовог 
одраза у води да би друго поглавље збирке „Ритуали, кретање модрог корења“ упутили читаоца у подземни свет земље. Ако први део представља вода, други је трагање за отчаравањем у корену земље као другог основног елемента света. То је поезија која се развија из збирке у збирку новим поетичким и жанровским варијацијама са невероватном свежином новог духа који помера границе. Ана Ристовић и сама каже: „Моћ поезије сам најпре доживела кроз прозу: најпре, тај магијски реализам латиноамеричких писаца, онда поезија кроз импресију коју ми је откривала Вирџинија Вулф у својим романима. Неспутана и путена реч Растка Петровића пронађена пре „Откровења“ у његовим путописима, кроз опипљиво досезање лепоте. Фузијско, густо и енергијом натопљено писмо Силвије Плат најпре наслућено кроз звук „Стакленог звона“ које сам још као тинејџерка носила свуда са собом, као мали, црни молитвеник. Акустична визуелност Бродског, француски симболисти; Бодлер, и пре свега Волт Витмен и његова расутост. Нешто касније, пољска поезија: Шимборска, Милош, Херберт. Са друге стране незаобилазни Кавафи. А све то као једно велико таложење речи, звука и ритма. Отац ме је научио да сваки, па и најмањи предмет, има своју душу према којој се треба брижљиво односити. Откривати у свету чудесне детаље, не замарати се целином[... “" (Ристовић 1994: 14). Ана Ристовић је и ћерка Александра Ристовића, песника који је обележио период од касних 60-их у нашој поезији. Та породична веза са оцем је оставила трага у њеном изразу и само то би могло да буде предмет једне обимне студије. Од прве збирке поезија Ане Ристовић је песништво искуства,

9 Видети опшриније: Ана Ристовић, „ Трешњин цвет у Војводе Степе 42“, АРТ032, бр. 18, 2008, 45-48. 
лирског треперења, двоструких слика огледала, контапункта, одјеци Вирџиније Вулф и Лоренса Дарела. Свака следећа збирка је померање, изоштренији тон, прецизан и суптилан песнички језик саткан од алузија, слутњи, сна, наговештаја, треперавих нити пауковог ткања. Као што је приметио и Саша Радојчић ${ }^{10}$ то је „свет између сна и јаве, ничија земља, међупростор сновидности“. У песми „Нити“ из исте збирке Ана Ристовић сасвим посебним стилом и гласом комуницира са читаоцем: „У које иглено ухо ћеш уденути свет/који си поређала пажљиво/дуж танке паукове нити:/у оно кроз које већ можеш назрети/кап крви на врху кажипрста, истрајну у промени/облика,/или у оно кроз које и сами светови као презрени/очај,/перје суновраћених птица,/и без твог труда пролећу?“

Следећа збирка Уже og иеска (1997) је композициони контрапункт саткан од поетског, лирског, фаталности пешчане куле и имагинације која превазилази реалност. Песнички говор Ане Ристовић је обележен имагинацијом која жели да проговори о ономе чега нема, невидљивом, а присутном. То је говор о одсутном или само ономе о чему машта песнички субјект. Забава за gоконе кћери (1999) је померила песнички израз ка најинтимнијем делу женског бића, духовном и телесном свету. Место жене и развој њеног емотивног живота је простор у коме се одвијају најделикатније трауме и најлепши доживљаји једног бића. То је песнички глас који казује о интимности која почива на потпуној „раздробљености и удаљености“, како каже и сама песникиња. Трећа књига је донела меланхолију и страст, како је приметио и Зоран Богнар ${ }^{11}$. Истовремено, то је

10 Видети: Саша Радојчић, „Оно што само песнички језик може“,

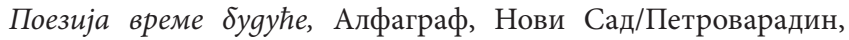
2003, 46-49.

11 Видети: Зоран Богнар, „ Меланхолија и страст“у: Борба, Год. 78, 
страст за животом и опирање двојним сликама свакодневице, обухваћена иронијом и аутоиронијом. Поред интимног и емоционалног језгра Ана Ристовић је вештим језичким обртима отварала и затварала мисаони свет жене. Трећа књига је донела и бројне референце на филозофију и историју књижевности (Паунд, Сизиф, Лајбниц, Спиноза, Кјеркегор, Витмен, Бодлер, Павезе). То је поезија која сублимира искуство, еротичност, мисаоност и емоцију као у песми „Спуштене завесе“: „Не бој се, не узмичи, ни уздрхтати немој:/читав свет је мало земље, у парку,/између два погнута старца незнанца/које је спојио случајни сусрет.//Док у тишини, вековима зуре у исто:/фотографију неке наге, бестидне кћери/што посматра их са хрпице лишћа-/обневиделима, чини нам се, сва у белом./Или тако једно другог слажу. Песма „Око нуле“ је извориште из кога ће израсти нова збирка Око нуле и ту налазимо низ поетичких поступака јер се често у раним збиркама налазе песме или поглавља која ће бити основа за нове збике. „Око нуле“ је песма у којој се гласом независне жене проговара о свим заблудама модерних жена, свим сновима дискретног женског бића опхрваног модерном цивилизацијом. У покушају да се буде независна и помало још старомодна жена губи себе, смисао, телесност и напокон остаје сама са својим жудњама и заблудама. „Независне смо жене./У ишчекивању нове љубави/дишемо астматично. Хранимо се пилулама/неиспуњених обећања. Тонемо у мутне снове./Двадесет и четири часа болно водимо љубав/са мигреном/и опраштамо јој јер је женског пола.“ У овој песми као и у наредној збирци Ана Ристовић проговара песничким језиком и свим грешкама независности жене које је доводе у тишину и

бр. 62, 2000, стр. 3. 
самоћу ноћних сати. Један од најинтимнијих тренутака усамљене, а независне жене жртве заблуда о модерном браку остају саме са собом и песничко ја у последњој строфи поентира: „[...] независне, кажемо, више но икад./А у осамљеним ноћима, у уску вулву/спуштамо свој чудесни прстић све чешће, као да убацујемо метак у пушчану цев/која опалити неће./И смешимо се, с тугом, у сну без снова./И рука је на сигурном, док кружи/ око меке нуле“. У песми „Опипљиво“ у истој збирци песникиња се позива на Спинозу: „Над земљином полулоптом,/у сочивима, брушеним Спинозином руком/ одражавају се два тела исте одсутности“. Тако се сабирају искуства и животна и читалачка у магму песничког бића обележеног гласом жене 21. века који тражи ново место за песнички субјект и жену распету између дужности и свог исконског изгубљеног сопства.

Ана Ристовић збирком Животи на разіллеgници (2003) која је веома блиска жанровском облику Ийаке и коменитара Милоша Црњанског веома успешно укршта жанр путописа и поезије путујући Шведском и позивајући се на Хиперборејце. Потом стижу Анини путописи из Словеније. Повезујући песништво и путовања као нова открића, варијације и експеримент путописа, есеја и поезије Ана Ристовић отвара и антрополошко питање човека Балкана који се померио са свог простора, али путујући он носи са собом бреме цивилизацијског кашњења у односу на нове, тек посећене просторе. Око нуле је збирка 42 страха произашла из првобитне песме из збирке Забава за gоконе кћери градећи тако комплексну слику фрустрација, боли личног и друштвеног окружења жене. Универзални страхови, али и наглашено песничко ја казују и о стању жене у свету у савремено доба и истовремено сведоче о ванременским страховима човека. Из тихог певања о стра- 
ховима стиже се у биће света, све оно што свет чини привлачним и опасним у исти мах. То су контроверзе постојања самог по себи у којима поезија глача оштре ивице света који гледа у сопствени понор. У низу свакодневних детаља израњају све боли и радости света, стрепње и страхови којима поезија неће дати смисао, али ће пружити нежност и топлину новог уточишта. У овој збирци последња песма „Чистина (страх од титраја крила)“ је основа из које ће настати последња збирка Чистиина (2015). То је страх од новог рађања, идеалне позиције на чистини, на осунчаном пропланку где нема нигде никога. На таквом месту расту крила. Да ли су то крила новог живота, нове песме, имагинације или моћи рађања, као што рече Растко Петровић? То је последњи страх који се трансформише у радост јер песничко биће постаје једно и јединствено са природом, травом и биљем те савршене чистине до које се стигло после свих страхова. То је и Дисовско утапање у погледу трава и нирвани песничке имагинације. P.S. су изабране песме које нису само избор дотадашњег публиковања већ и нови поглед на старе песме, синтеза у којој се срећу емоционалност и култура, образовање.

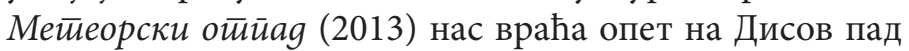
„из невиних даљина“ у ђубриште историје и наслеђе Шејкине златне кише која је донела нови живот. Ова збирка повлачи са собом и линију ка Пешчанику Данила Киша и осипању света, века, женског тела. Пред нама је комбинација меланхоличног и ироничног тона који се укршта са отрежњујућим референцама стварности, реалним сликама и свешћу да је пропадљивост нужност. Док су у ранијим збиркама светлели еротски узлети, слављење тела и културних референци као богатства света сада су ту већ стишанији тонови са искуством нестајања. Од виталистичке линије Расткове 
„Тајне рођења“ преко Дисовских нирвана и света што се осећа у погледу трава Ана Ристовић у Метиеорском oйūagy ${ }^{12}$ бива нови, зрелији поглед са Кишовим тихим нестајањем и осипањем. У изабраним и новим песмама Нешӣо светили (2014) извршена је нова рекапитулација песничког опуса у коме опет пред читаоцима израњају искуство живота и певања уједињено са културом која употпуњује песничке слике. Последња збирка Чистиина (2015) користи могућности циклусне организације у којој сваки од четири циклуса налази наставак у претходном. Последња збирка је један од облика епизације лирских циклуса који су се већ развили у нашој поезији од почетка 20. века и о којима смо опшриније и теоријски утемељено писали претходних година. Чистии$н a$, али и претходне збирке које се развијају из песама најранијих збирки као што је то песма „Око нуле“ и потом истоимена збирка указују на синтетичност опуса и специфичности изградње великих песничких целина из мањих песама које су поетичка, тематска и емоционална језгра или нека врста ембриона. То су аутентични поетички поступци Ане Ристовић, али их налазимо и у другом тематском језгру Ивана В. Лалића и принципу развоја тематике и симболике Византије. У Чисииини лирски јунак трага за собом, сопством и сада са дубоким осећањем горчине налази свој одраз у модерним технологијама, друштвеним мрежама, тетоважи покушавајући да дефинише свој профил. Мрежни или стварни? То је потрага за изгубљеним идентитетом као одјеком друштвеног бића у који могу да се упишу историја, култура и достигнућа у којима опет превладава сета и меланхолија већ препозната у ранијим збиркама

12 Видети: Бојана Стојановић Пантовић, „Бубриште и златна киша“, поговор у: Метееорски от̄йag, Културни центар Новог Сада, 2013, 91-99. 
Ане Ристовић. То није она светла чистина на којој се осећа радост и где је превладан страх од крила, новог рађања и остварења. Напротив, то је дисовска нирвана са погледом трава у којима се огледа песнички субјект. Ипак, то лирско ја успева да се измакне и да све то бива свет виђен са стране. Лирско ја бежи из таквог света у свој свет хедонизма, уживања у животу, лепим стварима и сласти, телесној, интелектуалној и гастрономској. Ово јесте поезија која песнички редефинише стварност, као што је приметио Предраг Петровић. Можда је чистина нови брисани простор у који могу да се упишу нова искуства и стара сазнања о свету јер овде као никада пре нема интертекстуалних наноса или су сведени на најмању могућу меру. Да ли је ово тренутак за велико чишћење сопства отежалог од искуства и тегобних емоција, знања или је то друштво које грца у неодостатку идентитета. Бојан Самсон сасвим тачно запажа да је Ана Ристовић постала представник поетике интимизма, другости и контрапункта. На тај начин је Ана Ристовић попут Десанке Максимовић већ формирана песникиња која је дала посебан допринос српској поезији улазећи у детаље личног и аутентичног света. Такав песнички израз обе песникиње различитих генерација није могао да буде део великих покрета и токова. За ту врсту поезије била је потребна самосвојна путања, увек ту, али довољно далеко да би била своја.

\section{Литература}

Бешић 2009: Бешић, Ален. „Поетика контрапункта“, поговор y: P.S., изабране песме. Краљево: Народна библиотека „Стефан Првовенчани“, 2009. 135-154.

Богнар 2000: Богнар, Зоран. „ Меланхолија и страст“. Борба, 
год. 78, бр. 62. (2000): 3.

Вранеш 2000: Вранеш, Александра. „Из рукописа Десанке Максимовић“. Слободан Ж. Марковић (ур.). Дело Десанке Максимовић у йоковима срйске и светиске книжевностии. Београд: Задужбина „Десанке Максимовић“, 2000. 132-138.

Ђорђевић 1998: Ђорђевић, Љубица. Песничко gело Десанке Максимовић. Панчево: ИП Пешић и синови, 1998.

Иванић 2007: Иванић, Душан „Ка оптималном критичком издању“. Ана Ћосић Вукић (ур.). Збирка Тражим йомиловаюе. Београд: Задужбина „Десанка Максимовић“, 2007. 83-92.

Јовановић 2013: Јовановић, Владимир. „Дела наших музичких стваралаца компонована на стихове Десанке Максимовић до 2001. године“. Станиша Тутњевић (ур.). Hag иелокуйним gелом Десанке Максимовић. Београд: Задужбина „Десанке Максимовић“, 2013. 391-410.

Поповић1960: Поповић, Богдан Љ. „Ракић, Шантић, Дучић и Антологија новије српске лирике“. Прилози КЈИФ, књ.26, св. 3/4 (1960).

Петров 2007: Петров, Александар. „С Богом их је троје“. Ана Ћосић Вукић (ур.). Збирка Тражим йомиловање. Београд: Задужбина „Десанка Максимовић“, 2007. 5-66.

Поповић 2008: Поповић, Ранко. „Лирски инстикт и вјековито памћење у поезији Десанке Максимовић“. Ана Ћосић Вукић (ур.). Траяиционално и модерно у сииваралашӣву Десанке Максимовић. Београд: Задужбина „Десанка Максимовић“, 2008. 55-70.

Радојчић 2014: Радојчић, Саша, „Имагинација и раст искуства“. Нешӣо свеитл: изабране и нове иесме. Чачак: Градска библиотека „Владислав Петковић Дис“, 2014. 107-115.

Радуловић 2014: Радуловић, Марија. Пуйоване у среgишйе сеঠе,каталог изложбе посвећен Ани Ристовић, добитници Дисове награде за 2014. годину. Чачак: Градска библиотека „Владислав Петковић Дис“, 2014.

Ристовић 1994: Ристовић, Ана. Сновияна воgа. Београд: Књижевна омладина Србије, 1994.

Ристовић 1994: Ристовић, Ана. „Продужетак детињства“ 
(интервју водио Зоран Радисављевић). Полиииика, год. 91, бр. 29057 (1994): 14.

Ристовић 2008: Ристовић, Ана „Трешњин цвет у Војводе Степе 42“, АРТ032, бр. 18 (2008): 45-48.

Ристовић 1997: Ристовић, Ана. Уже оg иееска. Београд: Градац, 1997.

Ристовић 1999: Ристовић, Ана. Забава за gоконе кћери. Београд: Рад, 1999.

Ристовић 2003: Ристовић, Ана, Животи на разілеgници. Београд: Плато, 2003.

Радојчић 2003: Радојичић, Саша. „Оно што само песнички језик може“. Поезија време бygyће. Нови Сад/Петроварадин: Алфаграф, 2003. 46-49.

Ристовић 2006: Ристовић, Ана. Око нуле. Краљево: Народна библиотека „Стефан Првовенчани“, 2006.

Ристовић 2013: Ристовић, Ана. Метееорски оӣūag. Нови Сад: Културни центар Новог Сада, 2013.

Ристовић 2014а: Ристовић, Ана. „Живот у ретровизору“. Радуловић, Марија, Пуйовағе у среgиште себе,каталог изложбе посвећен Ани Ристовић, добитници Дисове награде за 2014. годину. Чачак: Градска библиотека „Владислав Петковић Дис“, 2014. 5-6.

Ристовић 1994: Ристовић, Ана. „Продужетак детињства“, интервју водио Зоран Радисављевић. Политикка, год. 91, бр. 29057: 14.

Ристовић 20146: Нешӣо светили, изабране и нове йесме. Чачак: Градска библиотека „Владислав Петковић Дис“, 2014.

Ристовић 2015: Ристовић, Ана. Чистинна. Београд: Архипелаг, 2015.

Стојановић Пантовић 2013: Стојановић Пантовић, Бојана. „Ђубриште и златна киша“. Чистиина. Београд: Архипелаг, 2013. 91-99.

Тутњевић 2013: Тутњевић, Станиша. „Приступ цјелокупном дјелу Десанке Максимовић“. Станиша Тутњевић (ур.). Наg целокуйним gелом Десанке Максимовић. Београд: Задужбина „Десанке Максимовић“, 2013. 9-33. 
Svetlana Šeatović

\title{
POETRY OF DESANKA MAKSIMOVIĆ AND ANA RISTOVIĆ - FORMS OF AUTHENTIC POETIC DEVELOPMENT
}

\begin{abstract}
Summary
In this paper we point to the authentic poetic development of poetry Desanka Maksimović as an example of a unique opus within Serbian literature of the $20^{\text {th }}$ century. Desanka Maksimovićs poetry is interpreted as a specific poetic model that was a special one in relation to contemporaries, from the first poems published in the beginning of the twenties to the latest collections and poems of the nineties. In the development of Serbian poetry, Desanka Makismović remained a symbol of lyrical subtlety, duration and popularity. At the end of the $20^{\text {th }}$ century, Ana Ristovic published the first collection of poems Snovidna voda (1994) only a year after the death of Desanka Maksimović. Ana Ristovićs poetry since then, has been marked by constant poetic development, exceptional communication and a pronounced lyrical tone. Ana Ristović is a poetess who moves the boundaries of Serbian poetry in the $21^{\text {st }}$ century with the deep looks of the lyric subject, duality and c contrapunct interventions. This paper will point on two route of woman poetess, one rounded up and others emerging at the highest aesthetic range of self-development.
\end{abstract}

Key words: Desanka Maksimović, Ana Ristović. 